A. A. Shevchenko, orcid.org/0000-0002-6009-2387, M.M.Zipunnikov, orcid.org/0000-0002-0579-2962, A. L. Kotenko, orcid.org/0000-0003-2715-634X
A. M. Pidhorny Institute of Mechanical Engineering Problems of NASU, Kharkiv, Ukraine. e-mail: shevchenko84@ukr.net

\title{
ADAPTATION OF THE HIGH-PRESSURE ELECTROLYZER IN THE CONDITIONS OF JOINT OPERATION WITH TPP AND NPP POWER-GENERATING UNITS
}

Purpose. To substantiate the need to adapt the high pressure electrolyzer (HPE) to the conditions of joint operation with TPP and NPP power generating units to solve the problem of operating power generating units in the basic mode and to ensure the use of excess electrical power produced during periods of its minimal consumption for generating hydrogen and oxygen with their subsequent use during the electrical power peak consumption. This will allow reducing the number of "start - stop" modes caused by unevenness of the of electrical consumption schedule.

Methodology. Studying of electrochemical process of hydrogen and oxygen generation for their subsequent use in the technological schemes of TPP and NPP power generating units is based on the laws of mass conservation, thermodynamics, electrical engineering and electrochemistry when applying the data obtained from simulation and physical modeling methods.

Findings. We have studied the peculiarities of the use of hydrogen as a fuel under electrical energy production. The product of hydrogen combustion in oxygen is superheated water vapor - the working substance of modern steam turbines. The steam can be sent to a steam turbine where it performs an operation expanding. There were analyzed prospects of joint operating the power generating units with a high-pressure electrolyzer under the basic mode when the excess electricity produced in the minimal consumption periods was used for generating hydrogen and oxygen. Ways for modernization of the existing steam turbine installations were offered for work on variable modes (including the peak electrical energy consumption). Technological schemes of TPP and NPP power generating units have been improved and thermodynamic parameters of the cycles have been increased.

Originality. The calculated data show that when a steam turbine cycle is carried out with hydrogen superheated steam at $\alpha \leq 10^{1}$, the thermodynamic efficiency of the hydrogen fuel use can be 1.5-2 times higher than efficiency of the natural gas use in gas turbines, and the coefficient of electrical power regeneration can be from 40 to $50 \%$.

Practical value. A scheme for arranging the block of four electrolysis cells modules and a schematic diagrams of the basic types of hydrogen-oxygen steam generators have been developed; a set of works was completed aimed at developing scientific and technical principles for creating the new highly economic power generating units of increased maneuverability.

Keywords: electrolyzer, hydrogen, oxygen, steam generator, steam-gas turbine

Introduction. The most important feature of hydrogen as a fuel for energetics is that the product of its combustion in oxygen is superheated water vapor - the working fluid of the modern steam turbines. This water vapor can be directed to a steam turbine, where it does its job when expanding.

It is possible to use the excess electrical energy produced during the low consumption periods to generate hydrogen and oxygen. And it is one of the promising directions to solve the problem of ensuring of the power plant operation in the basic mode.

Gas generation under high pressure (up to $70.0 \mathrm{MPa}$ ) makes it possible to store them in storage under high pressure without using intermediate compressor equipment. As a result, it is possible to use them later during the electrical net peak loads directing them to the hydrogen-oxygen steam generator. And then superheated steam enters the turbine.

The studies in this area pay special attention to the organizational and technical measures to reduce the number of the power plant's "start-stop" modes. These modes are the forced ones due to the growing unevenness of the daily electric load schedule. There are many power plants where the number of such modes significantly exceeds the regulated one. The average monthly values of the daily range regulation of 200300 MW capacity power plants are of 21 to $29 \%$ [1].

Such operation causes low-cycle fatigue of rotors and other details and their premature failure earlier than the designated service life. This negative effect is increased by aging of the materials at high temperatures and reducing their plastic properties. The problem of increasing the number of the "start-stop" modes is particularly acute in the summer peri-

(C) Shevchenko A. A., Zipunnikov M. M., Kotenko A. L., 2020 ods. The reason for this is the electrical power excess - its low consumption.

It is possible to use the excess electrical energy produced during the low consumption periods to generate hydrogen and oxygen. And it is one of the promising directions to solve the problem of ensuring the power plants operation in the basic mode.

To realize this aim we propose creating the shops for electrolysis hydrogen production at the power plants [2].

In this case, a part of the generated hydrogen is used as a "candlestick" gas at solid fuel thermal power plants (TPP), and the other part is delivered to the existing gas transmission network, which can be used as a hydrogen accumulator of large capacity [3].

The content of hydrogen in the mixture with natural gas at the level of 3-5\% by volume does not require changing the technology of this mixture use in the municipal and industrial economy sectors.

The optimal organization of these processes by introducing the innovative hydrogen technologies is impossible without taking into account the peculiarities of the modes of joint operation of TPPs and NPPs with electrochemical generators of high pressure hydrogen and oxygen.

Purpose. The aim of this study is to develop the concept of a new electrochemical method for high pressure hydrogen and oxygen generation with high thermodynamic efficiency that provides adaptation of a high pressure electrolyzer (HPE) to joint operation with TPP and NPP.

In accordance with this aim, the following tasks are defined to be solved:

- to analyze the industrial methods of hydrogen generation and justify the effectiveness of HPE application for transfor- 
mation of the network excess electricity produced in the periods of low energy consumption;

- to study the ways for increasing the efficiency of the TPP and NPP power-generating units using the hydrogen generation technologies.

To solve these tasks we completed a set of studies by the directions:

- developing the scientific and technical principles of creating the new highly economy and maneuverable power units;

- providing the existing steam turbines' operation under variable modes (including "coverage" of the peak loads) by improving the technological schemes of TPP and TEC powergenerating units and by increasing the cycles thermodynamic parameters.

Industrial samples and perspective developments of the electrochemical hydrogen generators. The electrolytic technologies of hydrogen generation have been widely used in various modern technological processes due to electrochemical decomposition of liquid alkaline electrolyte [4]. A significant disadvantage of this method is its high energy consumption. Therefore, minimization of electricity consumption is currently a relevant task for hydrogen energetics in general. The scientists and engineers in many countries are solving this problem.

As to the modern technological schemes of hydrogen and oxygen generation by electrolysis, electrolyzers of the filterpress type are used. The well-known manufacturers are the following: "Uralkhimmash" firm [5]; TELEDYNE TITAN" ${ }^{\mathrm{TM}}$ [6]; HySTATTM [7]; Water project Flughafen Munich. Gesellschaft für Hochleistungselektrolyse - GHW [8]; Smart Hydrogen Station (SHS) [9]; HOGEN ${ }^{\circledR}[10]$. Electrolyzers produced by these manufacturers have the following working characteristics: range of working pressures from $0.05-$ $2.6 \mathrm{MPa}$; operating temperature from 333 to $353 \mathrm{~K}$; current density of $1200-2500 \mathrm{~A} / \mathrm{m}^{2}$.

The energy consumption depends on a number of factors, such as the process temperature, operating pressure of the generated gases, electrodes material, electrolyzer design, and can vary from 4.3 to $5.8 \mathrm{kWh}$ to produce $1 \mathrm{~m}^{3}$ of hydrogen and $0.5 \mathrm{~m}^{3}$ of oxygen.

A promising direction of electrolysis technology development is to use the filter-press type electrolyzers with proton exchange membranes (PEM). According to publications [11, 12], such electrolyzers generate hydrogen under relatively high pressure from 1.0 to $5.0 \mathrm{MPa}$.

The energy efficiency of the above-mentioned electrolyzers is achieved due to increasing the operating temperature up to $360 \mathrm{~K}$ and due to galvanic deposition of platinum or rare earth metals of the platinum group on the electrodes surface to play role of an electrochemical catalyst for the process. It causes a significant increase in electrolyzer price and complication of the technological scheme of electrode production as well as increasing the requirements for the accompanying maintenance processes, reducing the electrolyzer resource, and the most importantly, reducing its reliability through the use of distributing membranes.

One of the problems of the ion exchange membrane electrolyzer operation is significant pressure drop between the volumes of hydrogen and oxygen generation that may cause the membrane destruction.

This phenomenon is a major factor for limiting the operating pressure in such electrolyzers under hydrogen and oxygen generation.

The basic principles of the high-pressure membraneless electrolyzer operation. The scientists of the A.M. Pidhirny Institute of Mechanical Engineering Problems of National Academy of Sciences of Ukraine (IPMash NAS of Ukraine) have developed and tested the laboratory electrolyzer samples providing the innovative technology of membraneless high pressure hydrogen and oxygen generation [13].

This technology involves two cyclic redox reactions of the active mass of the gas-absorbing electrode.
The process of hydrogen generation begins with supplying the negative potential to the passive (gas-generating) electrode. At this stage, the active (gas-absorbing) electrode acts as an anode. The water decomposition reaction occurs with the simultaneous release of $\mathrm{H}_{2}$ and $\mathrm{O}_{2}$, but hydrogen is released at the gas-generating electrode in gaseous form and oxygen is chemically bound by a gas-absorbing electrode (it accumulates as a chemical compound) [14].

The electrolyzer power supply is synchronized with the electromechanical flow switch. And, as a result, hydrogen is released and fills only the hydrogen line, not mixing with oxygen.

When the limit voltage is reached, the polarity is switched with simultaneous powering of the electromechanical gas-liquid flow switch. As a result, the passive electrode becomes the anode and the active electrode becomes the cathode. Thus, only one gas is released - hydrogen or oxygen. There is no need to use the ion exchange membranes. The electrolysis process can take place at any pressure, limited only by the strength of the lectrolyzer's vessels and gas storage tanks.

The main advantages of the electrolysis equipment developed at IPMash of the NAS of Ukraine are its ability to operate with high energy efficiency feeding the power from the renewable energy sources [15]. Generating $1 \mathrm{~m}^{3}$ of hydrogen and $0.5 \mathrm{~m}^{3}$ of oxygen requires $3.9-4.0 \mathrm{kWh}$ [16] (Fig. 1).

This diagram shows that electricity consumption by IPMash's electrolyzer is 20-25\% lower than that of existing analogues. In addition, gases are generated at high operating pressures (from 15.0 to $70.0 \mathrm{MPa}$ ) [16] (Fig. 2).

The IPMash NASU electrolyzer provides the possibility for gas generation under operating pressure up to $70.0 \mathrm{MPa}$.

And this is the best indicator among the low-temperature alkaline electrolyzers. So, there are wide prospects for its application in the compressor-less hydrogen storage systems and subsequent to use hydrogen in the energy-technological complexes - Fig. 2.

To make a correct comparison of the energy efficiency of the membraneless high pressure hydrogen and oxygen gener-

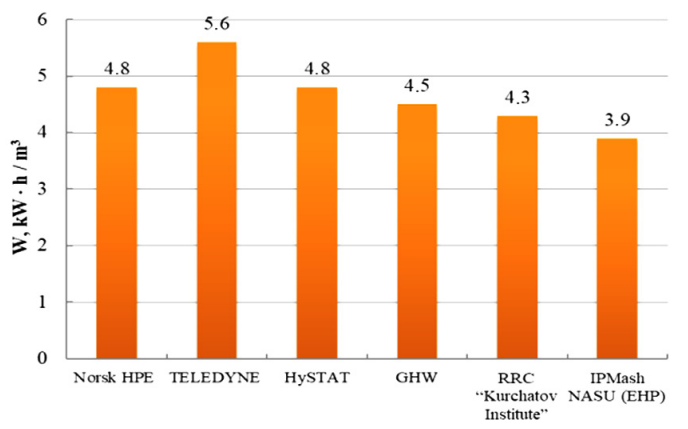

Fig. 1. Electricity consumption to generate $1 \mathrm{~m}^{3}$ of hydrogen and $0.5 \mathrm{~m}^{3}$ of oxygen by electrolyzers of various types

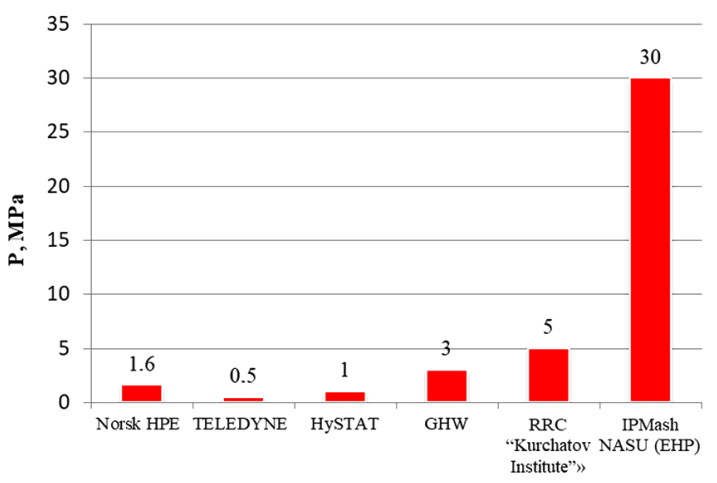

Fig. 2. Working pressure of the gases generated by the electrolysis equipment of various types 
Industrial electrolyzers and perspective electrolyzer developments

\begin{tabular}{|c|c|c|c|c|c|c|c|}
\hline \multirow{3}{*}{ Model } & \multirow{3}{*}{$\begin{array}{c}\mathrm{H}_{2} \text { generating } \\
\text { technology }\end{array}$} & \multicolumn{2}{|c|}{ Capacity } & \multirow{3}{*}{$\begin{array}{c}\mathrm{H}_{2} \text { pressure } \\
\text { (excess) } \\
\mathrm{MPa}\end{array}$} & \multirow{2}{*}{\multicolumn{2}{|c|}{$\begin{array}{l}\text { Electrical energy } \\
\text { consumption }\end{array}$}} & \multirow{3}{*}{$\begin{array}{c}\text { Purity of } \\
\mathrm{H}_{2}, \%\end{array}$} \\
\hline & & \multirow{2}{*}{$\frac{\mathrm{nm}^{3} / \mathrm{h}}{\max }$} & \multirow{2}{*}{$\frac{\mathrm{kg} / \mathrm{h}}{\max }$} & & & & \\
\hline & & & & & $\mathrm{kWh} / \mathrm{m}^{3}$ & $\mathrm{kWh} / \mathrm{kg}$ & \\
\hline Norsk HPE 10 & Bipolar alkaline cell & 10 & 0.9 & 1.6 & 4.8 & 53.4 & 99.8 \\
\hline TELEDYNE TITAN $^{\mathrm{TM}}$ EC-500 & Bipolar alkaline cell & 28 & 2.5 & $0.4-0.7$ & 5.6 & 62.3 & 99.9998 \\
\hline HySTAT-A1000Q-40-10 & Bipolar alkaline cell & 40 & 3.6 & 1.0 & 4.8 & 53.3 & 99.98 \\
\hline GHW & Bipolar alkaline cell & 110 & 9.9 & 3.0 & 4.5 & 55.5 & 99.7 \\
\hline RNC "Kurchatov Institute" & PEM & 10 & 0.9 & 5.0 & 4.3 & 47.7 & 99.98 \\
\hline Treadwell Corporation & PEM & 10.2 & 0.92 & 7.5 & & & 99.999 \\
\hline (EHP) IPMash NASU & Monopolar alkaline cell & 1.0 & 0.09 & $15.0-70.0$ & $3.9-4.1$ & 45.2 & 99.98 \\
\hline
\end{tabular}

ating technology and existing industrial electrolysis technologies, it is necessary to summarize the energy consumption for electrolytic hydrogen production using the above-mentioned industrial methods and its subsequent compression.

Table 1 shows the technical characteristics of existing and promising alkaline electrolyzers.

The design of the electrolyzer, implementing the proposed technology, includes an electrolysis unit, a system for separating gas-liquid streams, an electronic unit to manage and control the electrolyzer operation modes and the power supply unit.

Serial electrical connecting of the electrolysis cells gives the possibility to reduce the line current and, consequently, to reduce the copper consumption for the bus bars supplying power to the cells significantly. Fig. 3 represents the layout of the blocks and modules of four series-connected electrolysis cells (there should be ten cells altogether).

It is also promising to create powerful electrolysis plants that consume $25-30 \%$ of the network electricity and operate in buffer mode consuming the excess electricity in the periods of its low consumption by consumers.

Commissioning of such plants will ensure operating of the power-generating equipment of thermal power plants and nuclear power plants in the most economical and safe basic mode. Implementing such a project will require more than 1000 high-performance electrolyzers (up to $3000-5000 \mathrm{~m}^{3} / \mathrm{h}$ of hydrogen productivity).

For successful realization of this technological scheme, it is necessary to provide the technical conditions for balance of the generated and consumed hydrogen and oxygen quantity under joint operation of the TPP and NPP power-generating units and the hydrogen and oxygen electrochemical generators as early as at the stage of this scheme development.

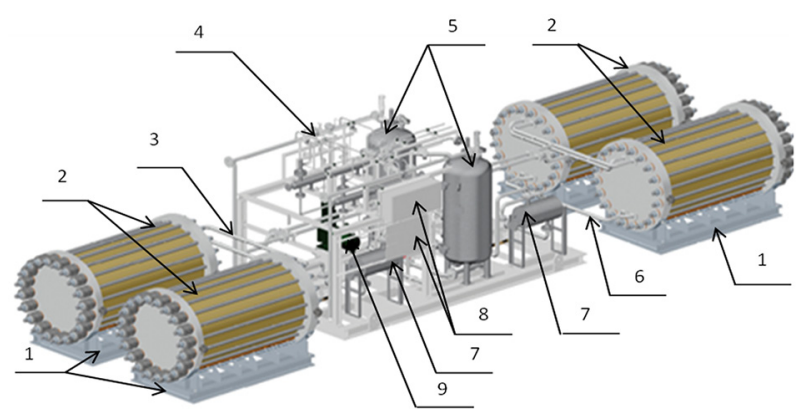

Fig. 3. Layout of the block of modules of four electrolysis cells: 1 - a frame of an electrolysis cell; 2 - electrolysis cells; 3 - gas line under operating pressure up to $70.0 \mathrm{MPa}$ s; 4 - gas-liquid flow switch unit; 5 - hydrogen and oxygen separators; 6 - electrolyte supply lines; 7 - containers with electrolyte; 8 - control and management system; 9 - pressure sensor
Optimization of gas and steam turbines working modes up to the needs of power consumption from the external power supply network. The idea to use the network excess of electrical energy requires developing of the new effective electrochemical methods of hydrogen generation. The most important hydrogen peculiarity as a fuel is that the product of its interaction with oxygen is the superheated water vapor - the working fluid of the steam turbines.

Entering the steam turbine, this vapor expands and performs the work. But its temperature is very high. Technologically, such vapor cannot be used directly in the turbine. The steam turbines operate at supercritical temperature values from 913 to $923 \mathrm{~K}$. Therefore, to reduce the water vapor temperature, it is necessary to add some water ( $n$ moles per 1 mole of $\mathrm{H}_{2}$ ). Then the work to be done by the water vapor per $1 \mathrm{~mole}$ of $\mathrm{H}_{2}$ is

$$
L_{\text {turbine }}=\left(\Delta H_{293}-n H_{s}^{\text {gas }}\right) \cdot \eta_{\text {turbine }},
$$

where $\Delta H_{293}=286 \mathrm{~kJ}$ per 1 mole of $\mathrm{H}_{2} ; H_{s}^{\text {gas }}$ is the enthalpy of the dry saturated steam at the pressure that is at the turbine outlet (it is assumed that after expansion in the turbine the vapor will be dry and saturated); $\eta_{\text {turb }}$ is the internal efficiency of the steam turbine.

To use hydrogen more efficiently, it is necessary to deliver the high-temperature water vapor into the operating steam turbine.

In this case, the high-temperature water vapor is mixed with slightly superheated or dry saturated steam in the turbine and, as a result, the temperature of the working substance increases resulting in the higher efficiency of the entire steam turbine cycle. The energy advisability of this method of hydrogen application is that the heat supplied by the high-temperature water vapor is realized in the cycle at the maximum allowable temperatures.

To realize this concept, it is proposed to implement the hydrogen-oxygen steam generators (HSG) in the power plants having the hydrogen-oxygen cycle or gas-turbine and steamturbine cycles, which include the combustion chambers and mixing chambers. Fig. 4 shows three main types of the hydrogen-oxygen steam generators.

Fig. 4, $a$ represents water vapor and water supply to the mixing chamber in the amount sufficient to provide the superheated steam with the specified parameters as a result of water evaporation and mixing it with the hydrogen combustion products.

Fig. 4, $b$ represents the process of water entering the mixing chamber. Fig. 4, $c$ represents the process of only steam entering the mixing chamber. Fig. 5 shows a diagram of the steam turbine power complex, where an electrolyzer is used to equalize the schedule of electricity consumption.

This scheme is implemented in the hours of "load failure" - low energy consumption. Hydrogen and oxygen are 


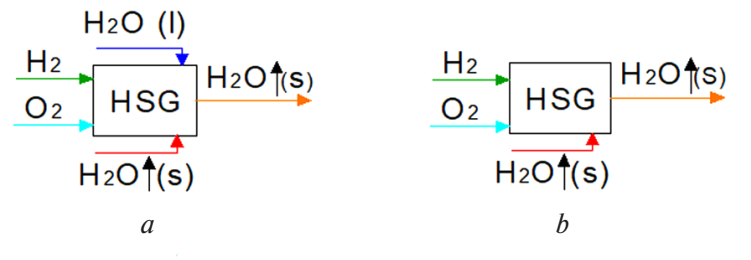

$$
\underset{c}{\mathrm{O}_{2}} \stackrel{\mathrm{HSG}_{2} \mathrm{O}(\mathrm{I})}{\mathrm{H}_{2} \mathrm{O} \uparrow(\mathrm{s})}
$$

Fig. 4. Schemes of the main types of hydrogen-oxygen steam generators:

$a-$ with injection of water and water vapor; $b-$ with water vapor injection; $c-$ with water injection

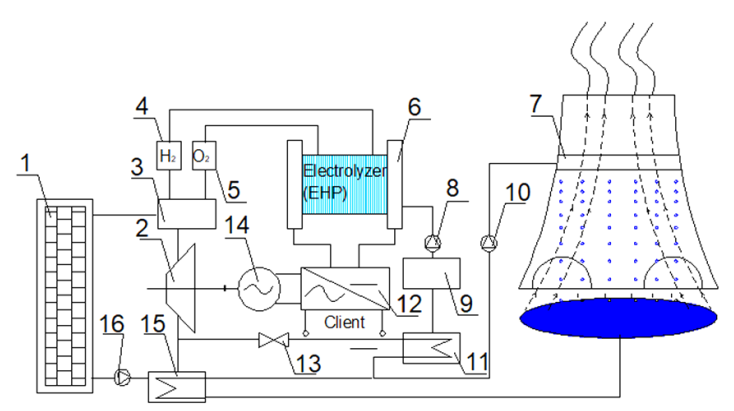

Fig. 5. The scheme of the power complex of the steam turbine with electrolyzer:

1-boiler; 2 - turbine; 3 - HSG; 4-hydrogen storage; 5 - oxygen storage; 6 - electrolyzer, 7 - air-drop heat exchanger (cooling tower); 8-pump to supply distillate to the electrolyzer; 9 - reserve storage of distilled water; 10 - pump to supply hot water to the cooling tower; 11 - distiller; 12 - conversion substation; 13 valve to supply steam to the distiller; 14 - electrogenerator; 15 condenser; 16 - water supply pump to the boiler

generated by water electrolysis with an initial pressure of $p_{e l}$. The gases are compressed to the operating pressure $p$ during electrolyzer operation and sent to the hydrogen and oxygen storage. When the electrical load reaches its peak value, hydrogen and oxygen enter the combustion chamber of HSG under $p_{2}^{1}$ pressure.

The superheated high-temperature steam, formed in the combustion chamber, is mixed in a mixing chamber with water vapor having $T_{0}$ temperature and $p_{2}$ pressure. As a result, the steam overheats, while its parameters vary from $p_{2}, T_{0}$ to $p_{2}, T_{k}$. Superheated steam enters the turbine, where it expands. Its parameters take the values of $p_{1}$ and $T_{1}$.

Due to the use of hydrogen, the operating cycle of a power plant operating without hydrogen superheating of steam (cycle $A$ ) will be converted into cycle $A+D$, with additional work $W$ equal to the area $D$ highlighted in red on the $T S$ diagram (Fig. 6 ).

At insignificant mass fractions of hydrogen combustion products $(\alpha-$ the ratio of the mass of hydrogen and oxygen combustion products to the total mass of steam entering into

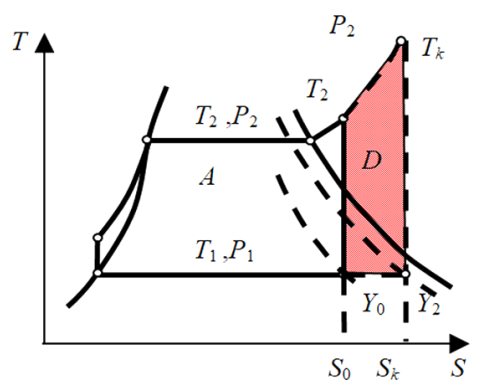

Fig. 6. TS-diagrams of the steam turbine cycle with water accumulators of energy [16]

the turbine) we obtain an analytical expression for the efficiency of hydrogen use in the cycle taking the heat capacity of steam $C_{p}=$ const [17]

$$
\eta_{\mathrm{H}_{2}}=\Delta W /\left(\alpha q_{\mathrm{H}_{2}}^{p}\right),
$$

where $q_{\mathrm{H}_{2}}^{p}$ is the lower heat of hydrogen combustion per $1 \mathrm{~kg}$ of the stoichiometric mixture combustion products. At $\alpha \rightarrow 0$, the heat of hydrogen combustion in oxygen will be converted into work with an efficiency closed to the efficiency of the Carno cycle at the former values of temperature $T=T_{0}$ and the relative internal efficiency of the turbine $\eta_{01}$, which is quite natural.

On this basis, we can assess the efficiency of electricity accumulation $\eta_{e f}$ (recovery factor - the ratio of $\Delta w$ to electricity consumed to produce hydrogen)

$$
\eta_{e f}=\eta_{\mathrm{H}_{2}} \cdot \eta_{e l} \cdot \eta_{s t},
$$

where $\eta_{e l}$ is the electrolyzer efficiency; $\eta_{s t}$ is the storage efficiency, taking into account the work spent on the hydrogen and oxygen compression to the pressure in the combustion chamber. For approximate estimates of $\eta_{\mathrm{H}_{2}}$ and $\eta_{e f}$, the values given in Table 2 were used.

The results of the calculation of the efficiency of the use of hydrogen obtained in the electrolyzer under pressure at $\eta_{s t}=1$ (Fig. 7)

High-efficiency high-pressure electrolyzers, developed at IPMash NASU, provide the excess network energy storage in the form of hydrogen and oxygen with their subsequent application of this energy during a power shortage period. The energy effect from application of hydrogen and oxygen is achieved due to increasing the steam turbine cycle temperatures, up to $972 \mathrm{~K}$, by the superheated water vapor. That results in increasing the power-generating plant efficiency and power output to cover uneven loads.

The use of modern heat-resistant materials in the turbine construction gives the possibility for increasing the initial cycle temperature from 850 to $1270 \mathrm{~K}$. Supplying hydrogen-oxygen mixture directly into the flowing part of the additional turbine, it may be possible to implement the process of steam expansion here that is to the uttermost closed to isothermal one. The efficiency of the power-generating unit will be $45-47 \%$, which is close to the performance of modern power-generating units, which are designed to operate at supercritical steam parameters.

The limit values do not exceed $10^{-1}$ and are determined by the maximum steam temperature allowed for turbines [18] (Fig. 8).

Thermodynamic quantities and their numerical values

\begin{tabular}{|c|c|c|c|c|c|c|c|c|c|c|}
\hline Size & $\begin{array}{c}C_{p}, \\
\mathrm{~kJ} / \mathrm{kg} \cdot \mathrm{K}\end{array}$ & $\begin{array}{c}r, \\
\mathrm{~kJ} / \mathrm{kg}\end{array}$ & $y_{0}$ & $\begin{array}{c}q_{\mathrm{H}_{2}}^{p}, \\
\mathrm{~kJ} / \mathrm{kg}\end{array}$ & $\begin{array}{c}T^{*}, \\
\mathrm{~K}\end{array}$ & $\begin{array}{c}H_{p}^{0}, \\
\mathrm{~kJ} / \mathrm{kg}\end{array}$ & $\begin{array}{c}T_{0}, \\
\mathrm{~K}\end{array}$ & $\begin{array}{c}T, \\
\mathrm{~K}\end{array}$ & $\eta_{e l}$ & $\eta_{01}$ \\
\hline value & 2 & $2.4 \cdot 10^{3}$ & 0.15 & $1.3 \cdot 10^{3}$ & 650 & $5.2 \cdot 10^{2}$ & 600 & 300 & 0.75 & 0.85 \\
\hline
\end{tabular}




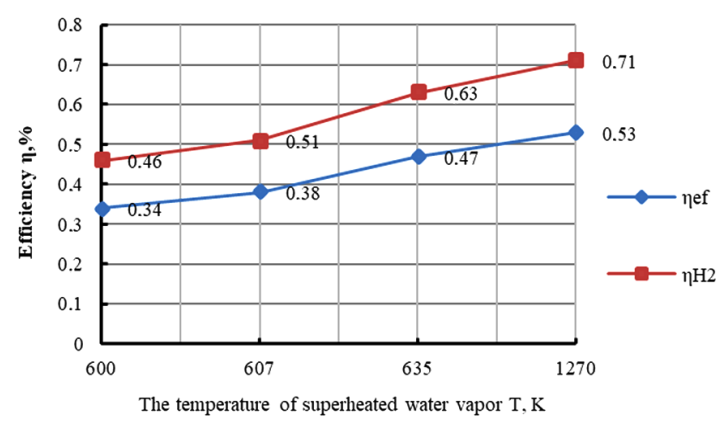

Fig. 7. Thermodynamic efficiency of the hydrogen use for superheating the steam under a steam turbine cycle

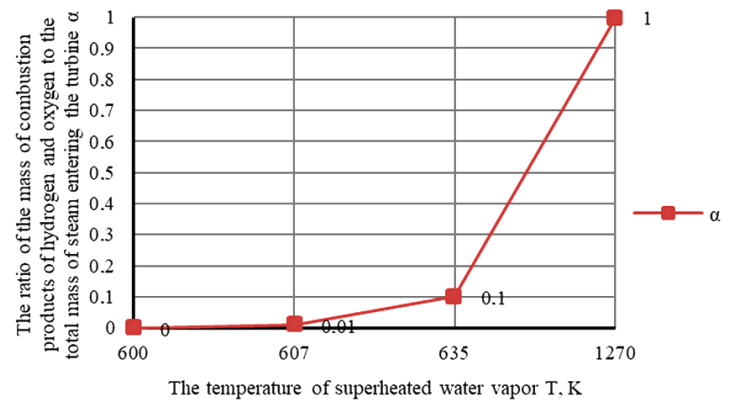

Fig. 8. Relationship of the ratio of the mass of hydrogen and oxygen combustion products to the total mass of steam entering into the turbine from the steam temperature

Under using intermediate hydrogen superheating of steam in HSG and under corresponding modernization of the steam turbines, further growth of $\eta_{\mathrm{H}_{2}}$ and $\eta \mathrm{l}$ can be achieved. The calculated data show that when performing a steam turbine cycle with hydrogen superheated steam at $\alpha \leq 10^{1}$, the thermodynamic efficiency of hydrogen application as a fuel can be 1.5-2 times higher than the efficiency of using the natural gas in the gas turbine plants. The coefficient of electricity recovery can be from 40 to $50 \%$ with increasing a: $\eta_{\mathrm{H}_{2}}$ and $\eta_{e l}$.

If the steam generator operates in the stationary mode and its productivity does not change, then the better regulation of power generating equipment is achieved through the use of the two turbines in the power plant - the main and additional ones, when the steam from the steam generator is redistributed between them with varying degrees of overheating.

For this type of the steam turbine plants, the increase in efficiency of hydrogen use is provided not only due to increasing the average thermodynamic temperature at which heat is supplied during a cycle, but also due to reducing the steam humidity at the turbine exhaust (increase $\eta_{01}$ ) as well as due to reducing the consumption of the superheated steam for inter- mediate overheating and reduction of regenerative bleed-off at use of the additional turbine. The decrease in the values of $\eta_{H}$ in comparison with the theoretical efficiency is explained by taking into account the exergic losses, energy consumption for hydrogen compression and the peculiarities of the processes realized in the modern turbines of the specific types (Fig. 9).

So, the results of the thermodynamic analysis of idealized schemes show that hydrogen energy storage, when hydrogen is used for steam superheating in the steam turbine cycle, can be a very effective method for balancing the electrical network power consumption schedule. And it is quite available method to put it into practice on the basis of existing equipment at the modern TPPs and NPPs [19].

Conclusions. As a promising direction of electrolysis techniques development, improvement of the membraneless technology should be considered for high pressure electrochemical generation of hydrogen and oxygen where the electrolyzer involves electrodes manufactured from the metals with variable valence. Such an electrolyzer is adapted to the use of the electricity from the renewable energy sources.

Increasing the thermodynamic cycle parameters and improving the technological schemes of TPP and NPP powergenerating units will result in the possibility for their operation in varied modes (involving "covering" the peak loads). And these results may be reached after execution of a set of works aimed at developing the scientific and technical principles of creating the new highly economical power-generating units of increased maneuverability.

The main advantages of the IPMash NASU electrolyzers are their high energy efficiency. The electrolyzer consumes $3.9-4.0 \mathrm{kWh}$ of electricity to obtain $1 \mathrm{~m}^{3}$ of hydrogen and $0.5 \mathrm{~m}^{3}$ of oxygen. It is $20-25 \%$ lower than electricity consumption by the existing electrolyzer analogues. In addition, the gases are generated at high pressure (from 15.0 to $70.0 \mathrm{MPa}$ ). So, there are wide prospects for their use in the compressorless hydrogen storage systems. The energy effect from application of hydrogen and oxygen is achieved due to increasing the steam turbine cycle temperatures, up to $972 \mathrm{~K}$, by the superheated water vapor. That results in increasing the power-generating plant efficiency and power output to cover uneven loads. Superheating hydrogen steam is especially effective in the cases where a steam generator produces the saturated steam that is typical for NPP steam generators. The thermodynamic efficiency of hydrogen application as a fuel can be 1.5-2 times higher than the efficiency of using the natural gas in the gas turbine plants. The coefficient of electricity recovery can be from 40 to $50 \%$.

Acknowledgement. The work was performed under the agreement NE.4.7-2020 of the Target Research Program of the National Academy of Sciences of Ukraine "Intelligent Environmentally Safe Energetics with Traditional and Renewable Energy Sources" ("New Energy").

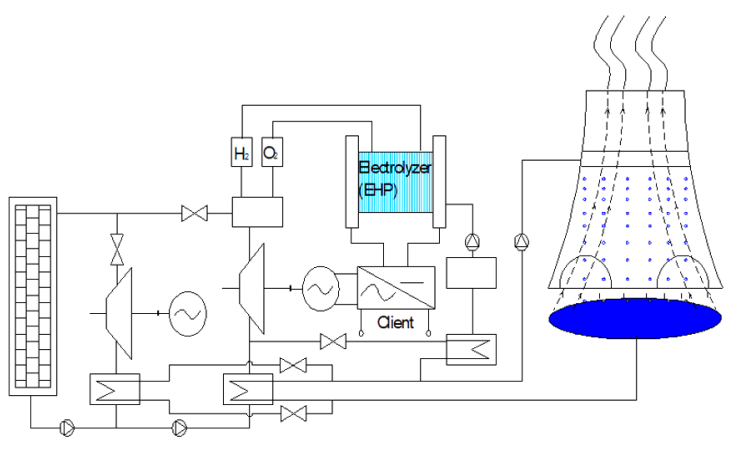

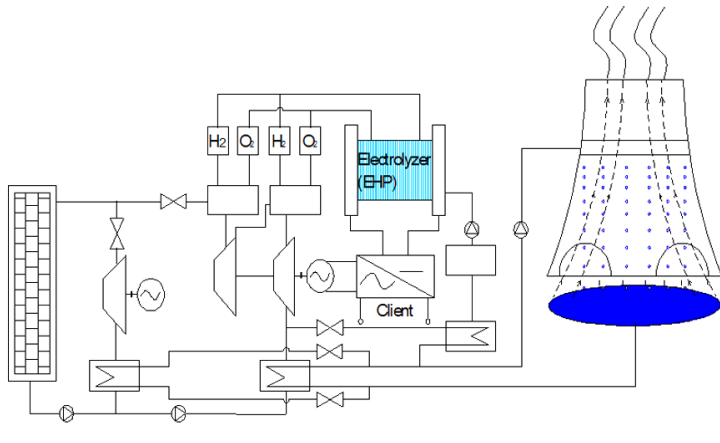

Fig. 9. Schematic diagrams of the steam turbine plants with electrolyzers intended for equalization of the power consumption schedules: $a$-plant with an additional turbine; $b$ - plant with the additional turbine realizing an intermediate overheating 


\section{References.}

1. Report on the assessment of compliance (sufficiency) of generating capacity (n.d.). Retrieved from https://ua.energy/wpcontent/uploads/2019/10/Zvit-z-otsinky-vidpovidnostivid-31.10.19.pdf.

2. Aminov, R. Z., Bairamov, A. N., \& Garievskii, M. V. (2019). Assessment of the Performance of a Nuclear-Hydrogen Power Generation System. Thermal Engineering, 66(3), 196-209. https://doi.org/10.1134/S0040601519030017.

3. Aminov, R.Z., Shkret, A.F., \& Garievskii, M.V. (2016). Estimation of lifespan and economy parameters of steam-turbine power units in thermal power plants using varying regimes. Thermal Engineering, 63, 551-557. https://doi. org/10.1134/S0040601516080012.

4. Dli, M. I., Baliabina, A. A., \& Drozdova, N. V. (2015). Hydrogen energy and development prospects. Alternative Energy and Ecology (ISJAEE), 22, 37-41. https://doi.org/10.15518/ isjaee.2015.22.004.

5. OAO "Uralkhimmash" (n.d.). Electrolyzers. Retrieved from https://elkt.com.ua/electrolyzers/28-electrolizer-fv.

6. TELEDYNE TITAN ${ }^{\mathrm{TM}} E C-500$ (n.d.). Retrieved from http://www.teledynees.com/products/Hydrogen\%200xygen\% 20Generation\%20Systems/Product\%20Files/TESI Brochure TITAN_EC Series_English_2013.pdf.

7. HySTATTM - A Energy Station (n.d.). Retrieved from: http://www.drivehq.com/file/df.aspx/isGallerytrue/shareID452352/fileID27809605? $1=1$.

8. Wasserstoffprojekt Flughafen München. Gesellschaft für Hochleistung Elektrolyse - GHW (n.d.). Retrieved from https:// www.linde gas.de/de/images/argemuc_projektbeschreibung tcm565-71308.pdf.

9. Smart Hydrogen Station (SHS) (n.d.). Retrieved from https://global.honda/innovation/FuelCell/smart-hydrogenstation-engineer-talk.html.

10. $H O G E N 囚 \mathrm{H}$ Series Technical Specifications (n.d.). Retrieved from https://diamondlite.com/wp-content/ uploads/2017/05/H-Serie-Englisch-1.pdf.

11. Langemann, M., Fritz, D., Müller, M., \& Stolten, D. (2015). Validation and characterization of suitable materials for bipolar plates in PEM water electrolysis. International Journal of Hydrogen Energy, 40(35), 11385-11391. https://doi. org/10.1016/j.ijhydene.2015.04.155.

12. Phillips, R., \& Dunnill, C. (2016). Zero gap alkaline electrolysis cell design for renewable energy storage as hydrogen gas. RSC Advances, 6(102), 100643-100651. https://doi. org/10.1039/C6RA22242K

13. Shevchenko, A., Zipunnikov, M., Kotenko, A., Vorobiova, I., \& Semykin, V. (2019). Study of the Influence of Operating Conditions on High Pressure Electrolyzer Efficiency. Journal of Mechanical Engineering, 22(4), 53-60. https://doi. org/10.15407/pmach2019.04.053.

14. Zipunnikov, M. M. (2019). Formation of potassium ferrate in a membrane-less electrolysis process of water decomposition. Issues of Chemistry and Chemical Technology. Dnieper, 1, 42-47. https://doi.org/10.32434/0321-4095-2019-126-5-4247.

15. Shevchenko, A. (2020). Creation of autonomous and network energy-technological complexes with a hydrogen storage of energy. Vidnovliuvana Energetika, 61(2), 18-27. https://doi. org/10.36296/1819-8058.2020.2(61).18-27.

16. Solovey, V. V., Khiem, N. T., Zipunnikov, M. M., \& Shevchenko, A.A. (2018). Improvement of the Membrane-less Electrolysis Technology for Hydrogen and Oxygen Generation. French-Ukrainian Journal of Chemistry, 6(2), 73-79. https://doi.org/10.17721/fujcV6I2P73-79.

17. Rusanov, A., Solovey, V., Zipunnikov, M., \& Shevchenko, A. (2018). Thermogasdynamics of physical and energy processes in alternative technologies. Thermogasdynamics of physical and energy processes in alternative technologies. PC “Technology Center." https://doi.org/10.15587/978-617-7319$\underline{18-3}$.
18. Aminov, R.Z., \& Bairamov, A. N. (2017). Performance evaluation of hydrogen production based on off-peak electric energy of the nuclear power plant. International Journal of Hydrogen Energy, 42, 21617-21625. https://doi.org/10.1016/j. ijhydene.2017.07.132.

19. Aminov, R.Z., Bairamov, A.N., \& Garievskii, M.V. (2020). Estimating the system efficiency of the multifunctional hydrogen complex at nuclear power plants. International Journal of Hydrogen Energy, 45(29), 14614-14624. https://doi. org/10.1016/j.ijhydene.2020.03.187.

\section{Адаптація електролізера високого тиску до умов спільної експлуатації з енергоблоками ТЕC і AEC}

\section{А. А. Шевченко, М. М. Зіпунніков, А. Л. Котенко}

Інститут проблем машинобудування імені А. М. Підгорного НАН України, м. Харків, Україна, е-mail: shevchenko84@ukr.net

Мета. Обгрунтування необхідності адаптації електролізера високого тиску (ЕВТ) до умов спільної експлуатації з енергоблоками ТЕС і АЕС для вирішення проблеми експлуатації енергоблоків у базовому режимі й забезпечення використання виробленої у «провальні» періоди надлишкової електричної енергії для одержання водню й кисню, з подальшим їх використанням під час піку електричного навантаження. Це дозволить скоротити кількість режимів «пуск - зупинка», обумовлених зростанням нерівномірності графіку електричного навантаження.

Методика. Дослідження процесу електрохімічного генерування водню й кисню, та їх подальшого задіяння в технологічних схемах енергетичних блоків ТЕС і АЕC, базується на законах збереження маси, термодинаміки, електротехніки, електрохімії з використанням даних, отриманих на основі методів імітаційного й фізичного моделювання.

Результати. Розглянуті особливості використання водню в якості палива для енергетики. Продуктом його згоряння в кисні є перегріта водяна пара - робоче тіло сучасних паротурбінних установок. Водяна пара може бути спрямована до парової турбіни, де, розширюючись, виконує роботу. Проаналізовані перспективи спільної експлуатації енергоблоків і електролізера високого тиску в базовому режимі з використанням виробленої у «провальні» періоди надлишкової електричної енергії для одержання водню й кисню. Запропоновані шляхи модернізації існуючих паротурбінних установок для роботи на змінних режимах (включаючи «покриття» пікових навантажень). Удосконалені технологічні схеми енергетичних блоків ТЕС і АЕС та підвищені термодинамічні параметри циклів.

Наукова новизна. Розрахункові дані показують, що при здійсненні паротурбінного циклу з водневим перегрівом пари при $\alpha \leq 10^{1}$ термодинамічна ефективність (ККД) використання водневого палива може бути в 1,52 рази вище, ніж ККД використання природного газу в газотурбінних установках, а коефіцієнт рекуперації електроенергії може становити від 40 до $50 \%$.

Практична значимість. Розроблена схема компонування блоку модулів із чотирьох електролізних комірок і принципова схема основних типів водень-кисневих парогенераторів, виконано комплекс робіт, спрямованих на розробку науково-технічних принципів створення нових високоекономічних енергоблоків підвищеної маневреності.

Ключові слова: електролізер, водень, кисень, парогенератор, парогазова турбіна 


\section{Адаптация электролизера высокого давления к условиям совместной эксплуатации с энергоблоками ТЭС и АЭС}

\section{А. А. Шевченко, Н. Н. Зипунников, А. Л. Котенко}

Институт проблем машиностроения имени А. М. Подгорного НАН Украины, г. Харьков, Украина, e-mail: shevchenko84@ukr.net

Цель. Обоснование необходимости адаптации электролизера высокого давления (ЭВД) к условиям совместной работы с энергоблоками ТЭС и АЭС для решения проблемы эксплуатации энергоблоков в базовом режиме и обеспечения использования произведенной в «провальные» периоды избыточной электрической энергии для получения водорода и кислорода, с последующим их использованием в пиковые режимы электрической нагрузки. Это позволит сократить количество режимов «Пуск - остановка», обусловленных ростом неравномерности графика электрической нагрузки.

Методика. Исследование процесса электро-химического генерирования водорода и кислорода, и их дальнейшего задействования в технологических схемах энергетических блоков ТЭС и АЭС, базируется на законах сохранения массы, термодинамики, электротехники, электрохимии с использованием данных, полученных на основе методов имитационного и физического моделирования.

Результаты. Рассмотрены особенности использования водорода в качестве топлива для энергетики. Продуктом его сгорания в кислороде является перегретый водяной пар - рабочее тело современных паротурбин- ных установок. Водяной пар может быть направлен в паровую турбину, где, расширяясь, выполняет работу. Проанализированы перспективы совместной эксплуатации энергоблоков и электролизера высокого давления в базовом режиме с использованием произведенной в «провальные» периоды избыточной электрической энергии для получения водорода и кислорода. Предложены пути модернизации паротурбинных установок для работы на переменных режимах (включая «покрытия» пиковых нагрузок). Усовершенствованы технологические схемы энергетических блоков ТЭС и АЭС и повышены термодинамические параметры циклов.

Научная новизна. Расчетные данные показывают, что при осуществлении паротурбинного цикла с водородным перегревом пара при $\alpha \leq 10^{1}$ термодинамическая эффективность (КПД) использования водородного топлива может быть в 1,5-2 раза выше, чем КПД использования природного газа в газотурбинных установках, а коэффициент рекуперации электроэнергии может составлять от 40 до $50 \%$.

Практическая значимость. Разработана схема компоновки блока модулей из четырех электролизных ячеек и принципиальная схема основных типов водород-кислородных парогенераторов, выполнен комплекс работ, направленных на разработку научно-технических принципов создания новых высокоэкономичных энергоблоков повышенной маневренности.

Ключевые слова: электролизер, водород, кислород, парогенератор, парогазовая турбина

Recommended for publication by O. L. Shubenko, Doctor of Technical Sciences. The manuscript was submitted 12.03.20. 